\title{
The Effects of Widening Daily Stock Price Limits on the Relevance between Audit Quality and Stock Return
}

\author{
Sang-Hyun JI*, Ki-Chang YOON**
}

Received: February 10, 2020 Revised: March 1, 2020 Accepted: March 6, 2020.

\begin{abstract}
The study investigates the effect of the widened daily stock price limits on the usefulness of accounting information in Korea: 1) whether investors place a higher importance on audit quality, an indicator of the reliability of accounting information, and 2) whether there are differences in the relationships between audit quality and stock-price earning-rates two years before and after June 15, 2016. This study employs samples of two years (2013 to 2015) before the widening and two years after the widening (2016 to 2017). The samples are limited to the companies listed on the Korea Stock Exchange, accounting settled in December, collected from Fn-Guide and TS-2000 of the Korea Listed Companies Association. The results show that the positive association between audit quality and stock return was increased during the later period, compared to the preceding period. This tendency was more evident in companies with higher debt ratios and companies with lower levels of income smoothing, which is considered to have higher risks. The findings suggest that it is the first study evaluating the effect of widening daily stock price limits, made on June 15, 2015, on the usefulness of audit quality information by examining the relevance between audit quality and stock return.
\end{abstract}

Keywords: Audit Quality, Debt Ratio, Income Smoothing, Stock Return, Widening Daily Stock Price Limit

JEL Classification Code: G30, M41, M42

\section{Introduction}

The Korea Exchange increased the daily stock price limit from $15 \%$ to $30 \%$ on June 15, 2015: It was the change made in KOSPI and KOSDAQ after 17 years and 10 years, respectively. The increase in the stock price daily limit was a result of the careful consideration of the enhancement of a price-discovery function, elimination of unfair trade practices, such as solidification of high/low limits, and stock dynamics, and at the time of writing, 2019, after 4 years, it is generally regarded successful.

Right before the increase in the stock price daily limit

*First Author. Assistant Professor, Division of Business \& Commerce, Baekseok University, Korea.

Email: shji@bu.ac.kr; and markwprior@naver.com

${ }^{* *}$ Corresponding Author. Assistant Professor, Department of Business Administration, Kunsan National University, Korea.

Email: kcyoon@kunsan.ac.kr

(c) Copyright: The Author(s)

This is an Open Access article distributed under the terms of the Creative Commons Attribution Non-Commercial License (http://Creativecommons.org/licenses/by-nc/4.0/) which permits unrestricted noncommercial use, distribution, and reproduction in any medium, provided the original work is properly cited. became effective, the market had mixed feelings about the change. In the stock market of Korea, greatly influenced by foreign funds, the increase in the stock price daily limit to $30 \%$ could increase the volatility of the stock market. However, it was revealed that volatility of stock prices has declined after the change in 2015. According to the Korea Exchange on July 20, 2017, during the second year of the widened daily stock price limit (June 15, 2016 to June 14, 2017), the no. of stocks reaching the upper price limit was 3.4 firms, 1.2 firms in the securities market and 2.2 firms in KOSDAQ. That was a significance decrease from 6.1 firms in the first year (June 15, 2016 to June 14, 2017), 2.4 firms in the securities market and 3.7 firms in KOSDAQ. In the year just before the daily stock price limit was increased from $15 \%$ to $30 \%$ (June $15,2014 \sim$ June 14, 2015), the average no. of stocks reaching the daily stock price upper limit and daily stock price lower limit were 19 firms and 4.2 firms, respectively. However, the average no. of stocks reaching the daily stock lower limit dropped sharply to 0.3 firms $\sim 0.4$ firms. The Korea Exchange said that the socalled magnet effect, which attracts investors as stock prices reaches the daily stock price limit, like magnet, had 
greatly eased, causing the abnormal surge to decrease. The magnet effect refers to a phenomenon in which, as a stock price approaches the price limit, the price limit attracts investors like magnets, increasing volatility. In addition, the volatility of stock index has been also decreased significantly. In the second year (June 15, 2016 to June 14, 2017), the average daily volatility of stock index was decreased to $0.7 \%$ and $1.0 \%$ in KOSPI and KOSDAQ, respectively. During the first year (June 15, 2016 to June 14, 2017), it reached $1.0 \%$ and $1.4 \%$, respectively, a bit higher than the year immediately before the change (June 15, 2014 to June $14,2015,0.8 \%$ for KOSPI and $1.1 \%$ for KOSDAQ), but it was reduced in the second year. Moreover, it was found that the widened daily stock price limit has supported the activation of stock trading.

Ever since the widening of daily stock price limits, the daily average trading volume has reached KRW 91 trillion, increased by $2.3 \%$ from the preceding period (KRW 89 trillion). Therefore, from these results, side effects, such as a delay in the price finding function of the market or the price of stocks reaching the upper/lower price limit affects the next-day prices, and excessive trading have been reduced, so it is possible to see that the widened daily stock price limits have exerted positive influences over the capital market.

On the other hand, ever since the widening of daily stock price limits, there have been a number of studies on the influence and effect of the widened daily stock price limits (Nguyen \& Nguyen, 2019). However, most of the previous studies focus on the effects of the widened daily stock price limits on the stock prices and stock market, but not on accounting information, which is a major variable of stock prices and a significant element of the stock investment. Therefore, this study focused the effect of the widened daily stock price limits on the usefulness of accounting information. To be more specific, since the widened daily stock price limits raise investment risks, usefulness of accounting information for making investment decisions is increased. Thus, this study examined whether investors place a higher importance on audit quality, an indicator of the reliability of accounting information.

This study has been constructed as follows. In the Chapter 1) Introduction, the background and purpose of this study are briefly presented. In the Chapter 2) Literature Review and Hypothesis, the trends of previous studies are reviewed and hypotheses are formulated. In the Chapter 3) Study Design, the process of sample selection and study models are presented (Kim, 2015). In the Chapter 4) Results of the Empirical Analysis, the results of hypothesis testing and additional analysis are presented. In the Chapter 5) Conclusion, this study is summarized and the significance and limitations of this study are stated.

\section{Literature Review and Hypothesisi}

\subsection{Literature Review}

Restriction of price range is to limit the fluctuation in stock prices to protect the stock market against a turmoil and induce fair stock prices. In the case of the stock market, the upper limit price is the price when the stock price reaches the upper limit of the daily stock price and the lower limit price is the price when the stock price reaches the lower limit of the daily stock price. In Korea, the restriction of price range was varied by each unit price till 1995 when the restriction of price range was set to be within $6 \%$.

In 1986 , it was increased to $8 \%$ and since June 15,2015 , the daily stock price limit is $30 \%$ in both KOSPI and KOSDAQ. In an efficient market, stock prices should fully reflect all the useful information in the immediate manner, but due to artificial measures such as daily stock price limits, they cannot. With the presence of daily stock price limits, when stock prices surge, the orders to sell stocks will far exceed the orders to purchase stocks and it will lead to the increase in the number of orders to purchase, in turn leading the increase in stock prices. On the other hand, when stock prices fall, the orders to purchase stocks will far exceed the orders to purchase stocks and it will lead to the increase in the number of orders to sell, in turn leading the decrease in stock prices (Nguyen \& Pham, 2018). For these reasons, generally in developed nations, there are no price limits or broad price limits. In the United States, it does not operate the upper and lower price limit system, but uses a circuit break (a system that stops the market itself for a certain period of time if the stock price fluctuates more than a certain percentage). On the other hand, for nations with the low level of openness of a financial market or the high level of financial market instability, daily stock price limits are in presence to secure the stability of a financial market and to protect investors, and Korea is one of such nations. So far, most of studies on daily stock price limits focus on the influence and effect of the daily stock price system and in specific, the influence of daily stock price limits on stock price volatility or trading volume volatility. However, results of these previous studies somewhat vary. The types of previous studies are as follows.

First, there are studies supporting the overreaction hypothesis, stating that the daily stock price limit system has a positive influence on the restriction of stock price volatility. According to the overreaction hypothesis, the daily stock price limit system can help restraining the investors' overreaction triggered by a specific event. In the studies by Brennan (1986), Ma, Rao and Sears (1989), and Kodres and O'Brien (1994), it is suggested that daily stock price limits plays a certain role in returning stock prices to 
their intrinsic values by giving investors a period of time to re-evaluate abrupt changes in stock prices or suppressing over-reactions to the imbalance between purchase orders and sell orders.

Second, there are studies suggesting that daily stock price limits rather increase stock volatility. Studies by Lee, Ready, and Seguin (1994), Berkman and Lee (2002) and others suggest that trades dealing with stock volatility or portfolio rebalancing rather pile up during a period of trade suspension, so stock volatility rather increases when the trades resume. Chung (1991) suggests that if daily stock price limits do not get reduced, they rather increase stock volatility. Lee, Ready, and Seguin (1994) suggests that stock volatility increases when stock prices reach daily stock price limits and the widening of daily stock price limits is also possible to increase an intra-day volatility rate.

Third, there are studies supporting the information hypothesis that the daily stock price limit system does not have any effects of restraining stock volatility. According to the information hypothesis, daily stock price limits have no influences on stock volatility: provided, since information interrupts the effective reflection of information on stock prices, stock volatility of the day is simply transferred to the next day, but it does not affect stock volatility. Kim and Rhee (1997) states that the width of daily stock price limits does not influence stock volatility, but it only disrupts the efficient reflection of information, so stock volatility of the day simply gets transferred to the next day.

\subsection{Hypothesis Formulation}

As addressed earlier, the widening of daily stock price limits in 15, 2015 has been shown to have a positive influence in the capital market, and it is clear that the risk of loss for individual investors becomes greater than before. For individual investors, who have less real-time responsiveness than foreign investors and institutional investors, are likely to suffer from greater losses due to widened daily stock price limits, in credit transactions that they borrow money and invest in the stock market. A few stocks with low trading volumes or low prices experienced sudden soaring and dropping in their prices, in the $20 \%$ range, not reaching the price limit, of $30 \%$, but still higher than the previous price limit. Therefore, private investors have the potential for greater losses after the widening of daily stock price limits.

This is further supported by the fact that their financing competences are limited compared to foreign investors and institutional investors, so the width of daily losses become also greater, and individual investors have virtually no countermeasures to cope with short selling strategies of foreign investors and institutional investors. Indeed, as the stock market plunged daily in August 2019 due to the US-
China trade dispute, exclusion of Korea from the whitelist of Japan, and failure of clinical experiments in bio companies, financial authorities of Korea reported that they would use temporary measures such as the reduction of daily stock price limits and deregulation of treasury shares. The reason that the financial authority came up with the possibility of a reduction in the daily stock price limit, after 4 years, was due to that Sillagen, which was the second largest stock in KOSDAQ, reached the daily stock price lower limit for four consecutive days after the DMC (Data Monitoring Committee), the US, recommended the suspension of the clinical trial of 'Pexa-Vec', its liver cancer medicine, and it was led to the abrupt dropping of KOSDAQ and created the great confusion in the market.

As seen from these cases, the widening of daily stock price limits could aggravate the confusion in the stock market and consequently, increase the investment risks of capital market investors. For investors whose investment risks become relatively higher due the widening of daily stock price limits, it might be possible for them to place more weights on accounting information, considered to be a more reliable investment index. However, since most investors cannot directly assess the reliability of accounting information provided by companies, the reliability of such accounting information can be indirectly determined based on the quality of external audit which can guarantee the reliability of the accounting information. Thus, the following hypotheses were formulated in this study.

Hypothesis: The widening of daily stock price limits increases the positive $(+)$ relevance between audit quality and stock return.

\section{Methodology}

\subsection{Sample Selection}

In this study, to evaluate the relevance between audit quality and stock return upon changes in investment risks of investors led by the widening of daily stock price limits, a period of 2 years (2013 to 2015) before the widening and of 2 years after the widening (2016 to 2017) were set to be the study period. For samples of this study, they were limited to the companies listed on the Korea Exchange, accounting settled in December, not in financial, insurance, lease, and real estate businesses, and with audit information which was evaluated to be proper, and financial information of such individual company was collected from Fn-Guide and TS-2000, of the Korea Listed Companies Association.

From 2,751 firm years for the study period of 4 years, 344 firm years for the companies of which financial information and stock returns were not available, 240 firm 
years for the companies of which BTD (book-tax difference) were not available, and 157 firm years in extreme ends [average $\pm 3(\mathrm{STD})]$ were excluded and total of 2,010 firm years became samples of this study. Table 1 shows the sample selection process.

Table 1: Sample Selection

\begin{tabular}{|c|c|}
\hline $\begin{array}{c}\text { Public Listed Company in the Korea Stock Exchange from 2013 } \\
\text { Non-Financial Industry }\end{array}$ & 2,751 \\
\hline $\begin{array}{c}\text { Companies with financial information not available at Fn-Guide } \\
\text { and TS-2000, companies without proper audit information, and } \\
\text { companies of which stock returns cannot be computed }\end{array}$ & $(344)$ \\
\hline $\begin{array}{c}\text { Companies of which BTD (book-tax difference) cannot be } \\
\text { computed }\end{array}$ & $(240)$ \\
\hline Extreme value [Average \pm 3 (standard deviation)] & $(157)$ \\
\hline Final number of samples & 2,010 \\
\hline
\end{tabular}

\subsection{Research Design}

In this model, by using the following study model, it is verified whether there is a difference in the positive relevance between audit quality and stock return between before and after the widening of daily stock price limits. For this, the entire samples are divided into two groups: the one for the period (2013 to 2014) before the widening, and another won for the period (2016 to 2017). Then, the positive relevance between audit quality and stock return for each group is verified and then, compared with each other. The actual analysis model of this study to test the hypothesis is as below:

$$
\begin{aligned}
\text { Ret }_{\mathrm{i}, \mathrm{t}} & =\beta_{0}+\beta_{1}\left(\mathrm{AQ}_{\mathrm{i}, \mathrm{t}}\right)+\beta_{2} \Delta \mathrm{EARN}_{\mathrm{i}, \mathrm{t}}+\beta_{3} \mathrm{EARN}_{\mathrm{i}, \mathrm{t}}+\beta_{4} \mathrm{SIZE}_{\mathrm{i}, \mathrm{t}} \\
& +\beta_{5} \mathrm{LEV}_{\mathrm{i}, \mathrm{t}}+\beta_{6} \mathrm{CFO}_{\mathrm{i}, \mathrm{t}}+\beta_{7} \mathrm{FOR}_{\mathrm{i}, \mathrm{t}}+\beta_{8} \mathrm{OWN}_{\mathrm{i}, \mathrm{t}} \\
& +\beta_{9} \mathrm{GRW}_{\mathrm{i}, \mathrm{t}}+\beta_{10} \mathrm{MTB}_{\mathrm{i}, \mathrm{t}}+\beta_{11} \mathrm{FirmAge}_{\mathrm{i}, \mathrm{t}}+\sum \mathrm{IND} \\
& +\sum \mathrm{YEAR}+\varepsilon
\end{aligned}
$$

- Ret: Monthly cumulative stock return for 12 months - AQ: Audit quality In many previous studies (Bedard, 1989; Davis, Ricchiute \& Trompeter, 1993; O'Keefe, Simunic, \& Stein, 1994; Stein, Simunic, \& O'Keefe, 1994; Hackenbrack \& Knechel, 1997; Felix \& Gramling, 2001; Johnstone \& Bedard, 2001; Raghunandan \& Rama, 2006; Bell, Doogar, \& Solomon, 2008; Hogan \& Wilkins, 2008; Hoitash, Hoitash, \& Bedard, 2008; Schelleman \& Knechel, 2010; Rahman, Meah, \& Chaudhory, 2019; Chae, 2020), $\mathrm{AF}$, and AT were used as proxy of audit quality.
(1) Audit time (AT): Standardized natural log value of total audit fee to total assets

(2) Audit fee (AF): Standardized natural log value of total audit fee to total assets

(3) Auditor scale (BIG4): 1 if audit has been made by one of 4 major audit firms, Samil, Samjung, Anjin, and Hanyeong, and 0 if not

(4) Book-Tax Difference (BTD): the methodology suggested by Park et al. (2006)

-Control Variables:

SIZE: Company size,

LEV: Debt ratio (total debt/capital)

CFO: cash flow from operating activities,

FOR: Foreigners' share

OWN: Major shareholders' share,

GRW: Total asset growth

MTB: Market-to-Book ratio,

FirmAge: Listing period

RET, the dependent variable of the aforementioned study model, is a monthly cumulative market adjusted return rate from April of the fiscal year to three months after the end of the fiscal year, and a market adjusted return rate is calculated by subtracting the equal weight average market return (EWI) from the individual company's return rate (Dang \& Tran, 2019; Vo, 2019). AQ is a proxy of audit quality and it includes AF, AT, BIG4 and BTD.

BTD was calculated by subtracting the taxable income from the income and loss before income taxes in the income statement and then, standardizing it with the total assets, and its absolute value was used for the analysis. Among proxies of audit quality, AF, AT, and BIG4 were proxies of audit quality from the perspective of audit while BTD was a proxy of audit quality from the perspective of audit output.

ab_BTD $D_{t}=\mid$ (income and loss before income taxes taxable income) $)_{t} /$ total assets $_{\mathrm{t}-1}$ |

Whereas, the taxable income reflecting the real tax burden was estimated by applying the real tax burden onto the tax calculation equation in the reverse.

* Taxable income $=[(($ corporate tax $/ 1.1)-$ standard tax base $\mathrm{x}$ tax rate under the standard tax base)/tax rate over the standard tax base] + standard tax base

* Corporate tax burden $=$ corporate tax + deferred income tax - deferred income household

\section{Result of Empirical Analysis}




\subsection{Descriptive Statistics}

Table 2 shows descriptive statistics of variables of the study model for testing the aforementioned hypothesis. In the case of RET, a dependent variable, it was 0.082. In the case of independent variables, 0.093 for AF, 0.059 for AT, 0.683 for BIG4, and absolute value of BTD (ab_BTD) was 0.043 . In the case of control variables, $\triangle \mathrm{EARN}$ was 0.002 and EARN was 0.054. In addition, FOR was 0.093, OWN was 0.464 , GRW was 0.016 , and MTB was 0.703 . On the other hand, since it was shown that in most variables, a difference between the mean and the media considering the standard variation, so it is possible to assume the standard distribution using these values ( $\mathrm{Ji}, 2019)$.

Table 1: Descriptive Statistics

\begin{tabular}{|c|c|c|c|c|c|}
\hline Variable & Mean & Median & $\begin{array}{c}\text { Std. } \\
\text { Deviation }\end{array}$ & MIN & MAX \\
\hline RET & 0.082 & 0.036 & 0.345 & -1.295 & 1.659 \\
\hline AF & 0.093 & 0.082 & 0.093 & 0.000 & 0.209 \\
\hline AT & 0.059 & 0.047 & 0.059 & 0.000 & 0.140 \\
\hline BIG4 & 0.683 & 1.000 & 0.466 & 0.000 & 1.000 \\
\hline ab_BTD & 0.043 & 0.032 & 0.039 & 0.000 & 0.226 \\
\hline$\triangle$ EARN & 0.002 & 0.000 & 0.050 & -0.256 & 0.401 \\
\hline EARN & 0.030 & 0.028 & 0.050 & -0.226 & 0.281 \\
\hline SIZE & 26.277 & 25.999 & 1.522 & 22.441 & 30.984 \\
\hline LEV & 0.888 & 0.651 & 0.892 & 0.001 & 8.233 \\
\hline CFO & 0.054 & 0.053 & 0.065 & -0.440 & 0.611 \\
\hline FOR & 0.093 & 0.050 & 0.103 & 0.000 & 0.492 \\
\hline OWN & 0.464 & 0.464 & 0.166 & 0.000 & 1.000 \\
\hline GRW & 0.016 & 0.030 & 0.614 & -25.385 & 0.617 \\
\hline MTB & 0.703 & 0.550 & 0.532 & 0.030 & 3.360 \\
\hline FirmAge & 8.799 & 9.063 & 0.820 & 5.908 & 10.025 \\
\hline
\end{tabular}

Table 3: Pearson correlation analysis

\begin{tabular}{|c|c|c|c|c|c|c|c|c|c|c|c|c|c|c|}
\hline & $\mathbf{A F}$ & AT & BIG4 & ab_BTD & RET & $\triangle$ EARN & EARN & SIZE & LEV & CFO & FOR & OWN & GRW & MTB \\
\hline \multirow{2}{*}{ AT } & $.998 * *$ & & & & & & & & & & & & & \\
\hline & 0.000 & & & & & & & & & & & & & \\
\hline \multirow{2}{*}{ BIG4 } & -0.032 & -0.006 & & & & & & & & & & & & \\
\hline & 0.183 & 0.789 & & & & & & & & & & & & \\
\hline \multirow{2}{*}{ ab_BTD } & $-.069^{* *}$ & $-.075^{* *}$ & -0.017 & & & & & & & & & & & \\
\hline & 0.004 & 0.002 & 0.469 & & & & & & & & & & & \\
\hline \multirow{2}{*}{ RET } & $-.223^{* *}$ & $-.224 * *$ & -0.040 & -0.044 & & & & & & & & & & \\
\hline & 0.000 & 0.000 & 0.091 & 0.065 & & & & & & & & & & \\
\hline \multirow{2}{*}{$\triangle \mathrm{EARN}$} & 0.026 & 0.027 & -0.037 & $-.068^{* *}$ & $.214 * *$ & & & & & & & & & \\
\hline & 0.278 & 0.250 & 0.123 & 0.004 & 0.000 & & & & & & & & & \\
\hline
\end{tabular}

\subsection{Relevance}

Table 3 shows the correlations among major variables of this study. They are Pearson's correlation coefficients, representing the bivariate correlation coefficients not considering other study variables or control variables $(\mathrm{Ji}$, Oh, Yoon, \& An, 2019). From the analysis, it was revealed that RET, a control variable of this study model, had a negative correlation with every independent variable (AF, AT, BIG4, ab_BTD) $(\mathrm{p}=0.1)$. In addition, RET was shown to have a positive correlation with each $\triangle \mathrm{EARN}, \mathrm{EARN}$, CFO, and MTB $(p=0.01)$, and a negative correlation with SIZE $(p=0.01)$. RET had a positive correlation with FirmAge $(p=0.1)$, but no significant correlation with LEV, FOR, OWN, and GRW. These results only represent the bivariate correlation between RET and each variable, excluding the control variable, so their meanings are very limited (An, Ryu \& Yoon, 2020).

\subsection{Results of the Hypothesis Testing}

Table 4 shows the results of the hypothesis testing using $\mathrm{AF}$ as a variable of audit quality. From the hypothesis testing, it was shown that there was no significant relevance between AF and RET in both the before-widening period (2013-2014) and the after-widening period (2016-2017). Therefore, the hypothesis that the positive relevance between audit quality and stock return increases after the widening of daily stock price limits was rejected.

Then, the results of hypothesis testing using the control variables during the before-widening period (2013-2014). First, RET was shown to have a positive relevance with each of $\triangle E A R N$, EARN, LEV, CFO, MTB, and FirmAge $(p=0.01)$. Second, SIZE was shown to have a negative relevance with RET ( $p=0.01)$. On the other hand, RET was shown to have no significant relevance with EARN, OWN, GRW, and GRW). 


\begin{tabular}{|c|c|c|c|c|c|c|c|c|c|c|c|c|c|c|}
\hline \multirow{2}{*}{ EARN } & $.065^{* *}$ & $.065^{* *}$ & $.056^{*}$ & $-.121^{* *}$ & $.160^{* *}$ & $.408^{* *}$ & & & & & & & & \\
\hline & 0.007 & 0.007 & 0.018 & 0.000 & 0.000 & 0.000 & & & & & & & & \\
\hline \multirow{2}{*}{ SIZE } & $.122 * *$ & $.147 * *$ & $.424 * *$ & $-.051^{*}$ & $-.187 * *$ & -0.046 & $.178 * *$ & & & & & & & \\
\hline & 0.000 & 0.000 & 0.000 & 0.032 & 0.000 & 0.056 & 0.000 & & & & & & & \\
\hline \multirow{2}{*}{ LEV } & $-.052 *$ & $-.047^{*}$ & 0.018 & 0.030 & 0.003 & 0.017 & $-.317 * *$ & $-.052 *$ & & & & & & \\
\hline & 0.028 & 0.049 & 0.449 & 0.211 & 0.909 & 0.487 & 0.000 & 0.030 & & & & & & \\
\hline \multirow{2}{*}{ CFO } & 0.022 & 0.024 & $.093 * *$ & -0.040 & $.150^{* *}$ & $.149 * *$ & $.505^{* *}$ & $.170^{* *}$ & $-.142 * *$ & & & & & \\
\hline & 0.353 & 0.311 & 0.000 & 0.097 & 0.000 & 0.000 & 0.000 & 0.000 & 0.000 & & & & & \\
\hline \multirow{2}{*}{ FOR } & 0.026 & 0.041 & $.262 * *$ & -0.015 & -0.023 & -0.005 & $.212^{* *}$ & $.609^{* *}$ & $-.135^{* *}$ & $.181 * *$ & & & & \\
\hline & 0.270 & 0.084 & 0.000 & 0.536 & 0.333 & 0.845 & 0.000 & 0.000 & 0.000 & 0.000 & & & & \\
\hline \multirow{2}{*}{ OWN } & 0.007 & 0.010 & $.081^{* *}$ & $-.099 * *$ & 0.009 & 0.003 & $.109^{* *}$ & -0.016 & $-.122 * *$ & $.088^{* *}$ & $-.244 * *$ & & & \\
\hline & 0.782 & 0.684 & 0.001 & 0.000 & 0.701 & 0.889 & 0.000 & 0.515 & 0.000 & 0.000 & 0.000 & & & \\
\hline \multirow{2}{*}{ GRW } & 0.029 & 0.029 & -0.016 & 0.013 & -0.020 & 0.034 & $.082 * *$ & 0.020 & -0.009 & 0.038 & 0.022 & -0.005 & & \\
\hline & 0.216 & 0.227 & 0.500 & 0.575 & 0.399 & 0.159 & 0.001 & 0.406 & 0.717 & 0.107 & 0.351 & 0.819 & & \\
\hline \multirow{2}{*}{ MTB } & $.070^{* *}$ & $.061^{* *}$ & 0.024 & $.170^{* *}$ & $.127^{* *}$ & $.065^{* *}$ & $.343 * *$ & $.332 * *$ & $-.325^{* *}$ & $.254 * *$ & $.236^{* *}$ & -0.030 & 0.036 & \\
\hline & 0.003 & 0.010 & 0.320 & 0.000 & 0.000 & 0.006 & 0.000 & 0.000 & 0.000 & 0.000 & 0.000 & 0.211 & 0.130 & \\
\hline \multirow{2}{*}{ FirmAge } & $.051 *$ & $.051^{*}$ & $-.130^{* *}$ & $-.050^{*}$ & 0.039 & -0.028 & $-.172 * *$ & $-.088^{* * *}$ & 0.044 & $-.135^{* *}$ & -0.014 & $-.103^{* *}$ & $-.049 *$ & $-.164^{* *}$ \\
\hline & 0.033 & 0.032 & 0.000 & 0.037 & 0.098 & 0.238 & 0.000 & 0.000 & 0.063 & 0.000 & 0.543 & 0.000 & 0.040 & 0.000 \\
\hline
\end{tabular}

Table 4: Changes in the Relevance between AF and Stock Return Led by the Widening of Daily Stock Price Limits

$\operatorname{Ret}_{\mathrm{i}, \mathrm{t}}=\beta_{0}+\beta_{1}\left(\mathrm{AF}_{\mathrm{i}, \mathrm{t}}\right)+$ Control Variables

\begin{tabular}{|c|c|c|c|c|c|c|}
\hline \multirow{2}{*}{ Variable } & \multicolumn{2}{|c|}{ Sample(2013-2014) } & \multicolumn{3}{|c|}{ Sample(2016-2017) } \\
& Coef. & $\mathbf{t}$ & $\mathbf{p}$ & Coef. & $\mathbf{t}$ & $\mathbf{p}$ \\
\hline Intercept & 1.921 & 4.637 & 0.000 & 1.078 & 2.716 & 0.007 \\
\hline AF & -2.308 & -1.276 & 0.202 & -0.002 & -0.001 & 0.999 \\
\hline$\Delta$ EARN & 0.846 & 3.621 & 0.000 & 1.535 & 6.212 & 0.000 \\
\hline EARN & 0.996 & 3.258 & 0.001 & -0.415 & -1.425 & 0.154 \\
\hline SIZE & -0.084 & -9.376 & 0.000 & -0.052 & -5.238 & 0.000 \\
\hline LEV & 0.041 & 2.988 & 0.003 & 0.030 & 2.053 & 0.040 \\
\hline CFO & 0.535 & 2.734 & 0.006 & 0.627 & 3.232 & 0.001 \\
\hline FOR & 0.182 & 1.328 & 0.184 & 0.573 & 4.182 & 0.000 \\
\hline OWN & 0.099 & 1.408 & 0.159 & 0.043 & 0.636 & 0.525 \\
\hline GRW & -0.010 & -0.822 & 0.411 & 0.006 & 0.056 & 0.955 \\
\hline MTB & 0.182 & 6.719 & 0.000 & 0.114 & 5.319 & 0.000 \\
\hline FirmAge & 0.059 & 4.269 & 0.000 & 0.008 & 0.651 & 0.515 \\
\hline YEAR & \multicolumn{3}{|c|}{ Included } & \multicolumn{3}{|c|}{ Included } \\
\hline F & \multicolumn{3}{|c|}{$11.468 * * *$} & \multicolumn{3}{|c|}{$5.778 * * *$} \\
\hline adjusted R & & .229 & & & .115 \\
\hline & & & & \\
\hline
\end{tabular}

1) $* * *, * *$ and $*$ is significant level at the $1 \%, 5 \%$ and $10 \%$ respectively (two-tailed)

2) VIF Max : 2.163
Table 5: Changes in the Relevance between AT and Stock Return Led by the Widening of Daily Stock Price Limits

Ret $_{\mathrm{i}, \mathrm{t}}=\beta_{0}+\beta_{1}\left(\mathrm{AT}_{\mathrm{i}, \mathrm{t}}\right)+$ Control Variables

\begin{tabular}{|c|c|c|c|c|c|c|}
\hline \multirow{2}{*}{ Variable } & \multicolumn{3}{|c|}{ Sample (2013-2014) } & \multicolumn{3}{c|}{ Sample (2016-2017) } \\
\cline { 2 - 7 } & Coef. & $\mathbf{t}$ & $\mathbf{p}$ & Coef. & $\mathbf{t}$ & $\mathbf{p}$ \\
\hline Intercept & 1.415 & 5.121 & 0.000 & 0.946 & 3.392 & 0.001 \\
\hline AT & 1.765 & 0.976 & 0.329 & 3.558 & 2.004 & 0.045 \\
\hline$\Delta$ EARN & 0.795 & 3.400 & 0.001 & 1.483 & 5.992 & 0.000 \\
\hline EARN & 1.104 & 3.613 & 0.000 & -0.346 & -1.191 & 0.234 \\
\hline SIZE & -0.089 & -8.946 & 0.000 & -0.063 & -5.513 & 0.000 \\
\hline LEV & 0.037 & 2.679 & 0.008 & 0.025 & 1.753 & 0.080 \\
\hline CFO & 0.517 & 2.644 & 0.008 & 0.617 & 3.193 & 0.001 \\
\hline FOR & 0.171 & 1.244 & 0.214 & 0.576 & 4.211 & 0.000 \\
\hline OWN & 0.107 & 1.537 & 0.125 & 0.047 & 0.695 & 0.487 \\
\hline GRW & -0.010 & -0.811 & 0.418 & 0.030 & 0.299 & 0.765 \\
\hline MTB & 0.180 & 6.647 & 0.000 & 0.123 & 5.640 & 0.000 \\
\hline FirmAge & 0.059 & 4.269 & 0.000 & 0.009 & 0.732 & 0.464 \\
\hline YEAR & \multicolumn{3}{|c|}{ Included } & \multicolumn{3}{c|}{ Included } \\
\hline F & \multicolumn{3}{|c|}{$11.432 * * *$} & & \multicolumn{3}{c|}{$5.957 * * *$} \\
\hline adjusted R & \multicolumn{3}{|c|}{.228} & & \multicolumn{3}{|c|}{} \\
\hline
\end{tabular}

1) $* * * * *$ and $*$ is significant level at the $1 \%, 5 \%$ and $10 \%$ respectively (two-tailed)

2) VIF Max : 2.292 
Table 5 shows the results of the hypothesis testing using AT as a variable of audit quality. From the hypothesis testing, it was shown that there was no significant relevance between AT and RET during the before-widening period (2013-2014), but a positive relevance during the afterwidening period $(2016-2017) \quad(p=0.05)$. Therefore, the hypothesis that the positive relevance between audit quality and stock return increases after the widening of daily stock price limits was supported.

Table 6 shows the results of the hypothesis testing using BIG4 as a variable of audit quality. From the hypothesis testing, it was shown that there was no significant relevance between BIG4 and RET during the before-widening period (2013-2014), but a positive relevance during the afterwidening period $(2016-2017)(\mathrm{p}=0.05)$. Therefore, the hypothesis that after the widening of daily stock price limits, the positive relevance between audit quality and stock return increases since the investment risks are expanded, in turn increasing the importance and usefulness of audit quality information was supported.

Table 6: Changes in the Relevance between BIG4 and Stock Return Led by the Widening of Daily Stock Price Limits Ret $_{i, t}=\beta_{0}+\beta_{1}($ BIG4i,t) + Control Variables

\begin{tabular}{|c|c|c|c|c|c|c|}
\hline \multirow{2}{*}{ Variable } & \multicolumn{3}{|c|}{ Sample (2013-2014) } & \multicolumn{3}{|c|}{ Sample (2016-2017) } \\
\hline & Coef. & $\mathbf{t}$ & $\mathbf{p}$ & Coef. & $\mathbf{t}$ & $\mathbf{p}$ \\
\hline Intercept & 1.569 & 5.905 & 0.000 & 1.205 & 4.371 & 0.000 \\
\hline BIG4 & 0.027 & 1.028 & 0.304 & 0.056 & 2.307 & 0.021 \\
\hline$\triangle \mathrm{EARN}$ & 0.820 & 3.525 & 0.000 & 1.536 & 0.239 & 6.251 \\
\hline EARN & 1.066 & 3.528 & 0.000 & -0.433 & -0.069 & -1.503 \\
\hline SIZE & -0.088 & -9.260 & 0.000 & -0.059 & -0.266 & -5.751 \\
\hline LEV & 0.039 & 2.823 & 0.005 & 0.029 & 0.078 & 2.063 \\
\hline $\mathrm{CFO}$ & 0.523 & 2.677 & 0.008 & 0.592 & 0.117 & 3.054 \\
\hline FOR & 0.169 & 1.228 & 0.220 & 0.561 & 0.183 & 4.106 \\
\hline OWN & 0.100 & 1.427 & 0.154 & 0.037 & 0.020 & 0.555 \\
\hline GRW & -0.010 & -0.833 & 0.405 & 0.019 & 0.007 & 0.196 \\
\hline MTB & 0.181 & 6.683 & 0.000 & 0.123 & 0.216 & 5.689 \\
\hline FirmAge & 0.060 & 4.341 & 0.000 & 0.013 & 0.033 & 0.983 \\
\hline $\begin{array}{l}\text { IND, } \\
\text { YEAR }\end{array}$ & \multicolumn{3}{|c|}{ Included } & \multicolumn{3}{|c|}{ Included } \\
\hline $\mathrm{F}$ & \multicolumn{3}{|c|}{$11.438 * * *$} & \multicolumn{3}{|c|}{$6.035 * * *$} \\
\hline adjusted $\mathrm{R}^{2}$ & \multicolumn{3}{|c|}{.229} & \multicolumn{3}{|c|}{.121} \\
\hline
\end{tabular}

1) ***,** and * is significant level at the $1 \%, 5 \%$ and $10 \%$ respectively (two-tailed)

2) VIF Max : 2.140

Table 7 shows the results of the hypothesis testing using BTD as a variable of audit quality. From the hypothesis testing, it was shown that there was no significant relevance between the absolute value of BTD (ab_BTD) and RET during the before-widening period (2013-2014), but a negative relevance during the after-widening period (20162017) $(\mathrm{p}=0.05)$. It means that the lower the ab_BTD after the widening of daily stock price limits, the higher the stock return. Therefore, the hypothesis that after the widening of daily stock price limits, the positive relevance between audit quality and stock return increases since the investment risks are expanded, in turn increasing the importance and usefulness of audit quality information was supported.

As shown from results of the hypothesis testing, in Tables 4, 5, 6, and 7, a positive relevance between audit quality and stock return was increased after the widening of daily stock price limits. Therefore, (excluding the analysis using audit fees) since it was shown that the importance and usefulness of audit quality information were increased after the widening of daily stock price limits, the hypothesis of this study was supported.

Table 7: Changes in the Relevance between BTD and Stock Return Led by the Widening of Daily Stock Price Limits Ret $_{i, t}=\beta_{0}+\beta_{1}\left(\mathrm{BTD}_{\mathrm{i}, \mathrm{t}}\right)+$ Control Variables

\begin{tabular}{|c|c|c|c|c|c|c|}
\hline \multirow{2}{*}{ Variable } & \multicolumn{3}{|c|}{ Sample(2013-2014) } & \multicolumn{3}{|c|}{ Sample(2016-2017) } \\
\hline & Coef. & t & $\mathbf{p}$ & Coef. & $\mathbf{t}$ & $\mathbf{p}$ \\
\hline Intercept & 1.598 & 6.060 & 0.000 & 1.173 & 4.343 & 0.000 \\
\hline ab_BTD & -0.474 & -1.412 & 0.158 & -1.096 & -3.673 & 0.000 \\
\hline$\triangle \mathrm{EARN}$ & 0.820 & 3.530 & 0.000 & 1.468 & 5.987 & 0.000 \\
\hline EARN & 0.925 & 2.973 & 0.003 & -0.420 & -1.465 & 0.143 \\
\hline SIZE & -0.087 & -9.632 & 0.000 & -0.052 & -5.410 & 0.000 \\
\hline LEV & 0.040 & 2.942 & 0.003 & 0.028 & 1.997 & 0.046 \\
\hline $\mathrm{CFO}$ & 0.538 & 2.753 & 0.006 & 0.601 & 3.127 & 0.002 \\
\hline FOR & 0.190 & 1.381 & 0.168 & 0.536 & 3.933 & 0.000 \\
\hline OWN & 0.102 & 1.459 & 0.145 & 0.019 & 0.284 & 0.777 \\
\hline GRW & -0.010 & -0.792 & 0.428 & 0.010 & 0.099 & 0.921 \\
\hline MTB & 0.191 & 6.871 & 0.000 & 0.133 & 6.096 & 0.000 \\
\hline FirmAge & 0.057 & 4.142 & 0.000 & 0.006 & 0.463 & 0.643 \\
\hline $\begin{array}{l}\text { IND, } \\
\text { YEAR }\end{array}$ & \multicolumn{3}{|c|}{ Included } & \multicolumn{3}{|c|}{ Included } \\
\hline $\mathrm{F}$ & \multicolumn{3}{|c|}{$11.548^{* * *}$} & \multicolumn{3}{|c|}{$6.431 * * *$} \\
\hline adjusted $\mathrm{R}^{2}$ & \multicolumn{3}{|c|}{.230} & \multicolumn{3}{|c|}{.129} \\
\hline
\end{tabular}

1) $* * *, * *$ and $*$ is significant level at the $1 \%, 5 \%$ and $10 \%$ respectively (two-tailed)

2) VIF Max : 2.129

\subsection{Additional Analysis}

In this study, it was empirically verified whether the increase in investment risks due to the widening of daily stock price limits were led to the increase in the usefulness and importance of audit quality information. On the other hand, investment risks could be varied by various factors: 
In general, the higher the debt ratio of a company to be invested, the poorer the financial soundness of that company, and therefore the higher the investment risk. In other words, companies with the higher debt ratio or higher stock return volatility have higher investment risks. Thus, for such companies, the importance and usefulness of audit quality information would increase further when investment risks are increased due to the widening of daily stock price limits. Considering that, this study further analyzed whether there was a difference in the positive relevance between audit quality and stock return between before and after the widening of daily stock price limits. The results are as follows.

\subsubsection{Depending on the Debt Ratio}

Debt ratios are a ratio of total debt to capital in the financial statement. It is used as an indicator of the soundness level of a company. Since it is proper for a company to have a debt less than its capital, 1 or $100 \%$ or less is proper. The higher the debt ratio, the financial structure is considered unhealthy. Companies with the higher debt ratios are likely to have the higher investment risks, so it might be possible to expect that the importance and usefulness of audit quality information became higher in such companies after the widening of daily stock price limits in 2015, increasing the investment risks. In the additional analysis, the entire samples were divided into two groups: the one with the debt ratios higher than the median, and another with the debt ratios lower than the ratio. Then, the positive relevance between audit quality and stock return for each group was verified and then, compared with each other.

Table 8 shows the results of the additional analysis, examining whether the positive relevance between audit quality and stock return became varied by a debt ratio, or not. First, in the panel A, there was no change in the positive relevance between $\mathrm{AF}$ and stock return, regardless of a debt ratio, after the widening of daily stock price limits. Second, in the group of samples with the higher debt ratios, in the Panel_B, there was a positive relevance between AT and stock return after the widening of daily stock price limits. However, in the group of samples with the lower debt ratios, no positive relevance between AT and stock return after the widening of daily stock price limits was shown. Third, in the group of samples with the higher debt ratios, in the Panel_C, there was a positive relevance between BIG4 and stock return after the widening of daily stock price limits.

However, in the group of samples with the lower debt ratios, no positive relevance between BIG4 and stock return after the widening of daily stock price limits was shown. Fourth, in the group of samples with the higher debt ratios, in the Panel_D, there was a negative relevance between BTD and stock return after the widening of daily stock price limits. However, in the group of samples with the lower debt ratios, no relevance between BTD and stock return after the widening of daily stock price limits was shown. In other words, in a group of samples with the higher debt ratios, the higher the audit quality, the higher the stock return. On the other hand, in a group of samples with the lower debt ratios, there was no significant relevance between audit quality and stock return. According to these results, in the case of companies with the higher debt rates, in turn having the higher investment risks, the positive relevance between audit quality and stock return was increased after the widening of daily stock price limits, so it is possible to conclude that participants of the capital market cope with the increased investment risks by expanding the usefulness of audit quality information.

Table 8: Changes in the Relevance between Audit Quality and Stock Return, Led by the Widening of Daily Stock Price Limits - By Grouping Samples Based on the Debt Ratio -

Ret $_{\mathrm{i}, \mathrm{t}}=\beta_{0}+\beta_{1}\left(\mathrm{AF}_{\mathrm{i}, \mathrm{t}}, \mathrm{AT}_{\mathrm{i}, \mathrm{t}}, \mathrm{BIG}_{\mathrm{i}, \mathrm{t}}\right.$, ab_BTD $\left.\mathrm{B}_{\mathrm{i}, \mathrm{t}}\right)+$ Control Variables

\begin{tabular}{|c|c|c|c|c|c|c|c|c|}
\hline \multicolumn{9}{|c|}{ Panel_A. Audit Fee and Stock Return } \\
\hline \multirow{3}{*}{ Variable } & \multicolumn{4}{|c|}{ Low Debt Ratio Group } & \multicolumn{4}{|c|}{ High Debt Ratio Group } \\
\hline & \multicolumn{2}{|c|}{$\begin{array}{c}\text { Prior Expansion } \\
(2013-2014)\end{array}$} & \multicolumn{2}{|c|}{$\begin{array}{l}\text { Post Expansion } \\
\text { (2016-2017) }\end{array}$} & \multicolumn{2}{|c|}{$\begin{array}{c}\text { Prior Expansion } \\
(2013-2014)\end{array}$} & \multicolumn{2}{|c|}{$\begin{array}{l}\text { Post Expansion } \\
\text { (2016-2017) }\end{array}$} \\
\hline & Coef. & $\mathbf{t}$ & Coef. & $\mathbf{t}$ & Coef. & $\mathbf{t}$ & Coef. & $\mathbf{t}$ \\
\hline Intercept & 1.699 & $2.798 * * *$ & 1.612 & $2.609 * * *$ & 2.869 & $5.253 * * *$ & .771 & 1.386 \\
\hline $\mathrm{AF}$ & 1.841 & 692 & -.268 & -.108 & -8.518 & $-3.552 * * *$ & -.945 & -.394 \\
\hline Control Variables & \multicolumn{2}{|c|}{ Included } & \multicolumn{2}{|c|}{ Included } & \multicolumn{2}{|c|}{ Included } & \multicolumn{2}{|c|}{ Included } \\
\hline Adj. $R^{2}$ & \multicolumn{2}{|c|}{.294} & \multicolumn{2}{|c|}{.094} & \multicolumn{2}{|c|}{.259} & \multicolumn{2}{|c|}{.158} \\
\hline F-value & \multicolumn{2}{|c|}{$9.514 * * *$} & \multicolumn{2}{|c|}{$3.040 * * *$} & \multicolumn{2}{|c|}{$7.289 * * *$} & \multicolumn{2}{|c|}{$5.001 * * *$} \\
\hline
\end{tabular}




\begin{tabular}{|c|c|c|c|c|c|c|c|c|}
\hline \multicolumn{9}{|c|}{ Panel_B. Audit Time and Stock Return } \\
\hline \multirow{3}{*}{ Variable } & \multicolumn{4}{|c|}{ Low Debt Ratio Group } & \multicolumn{4}{|c|}{ High Debt Ratio Group } \\
\hline & \multicolumn{2}{|c|}{$\begin{array}{c}\text { Prior Expansion } \\
(2013-2014)\end{array}$} & \multicolumn{2}{|c|}{$\begin{array}{c}\text { Post Expansion } \\
(2016-2017)\end{array}$} & \multicolumn{2}{|c|}{$\begin{array}{c}\text { Prior Expansion } \\
\text { (2013-2014) }\end{array}$} & \multicolumn{2}{|c|}{$\begin{array}{c}\text { Post Expansion } \\
\text { (2016-2017) }\end{array}$} \\
\hline & Coef. & $\mathbf{t}$ & Coef. & $\mathbf{t}$ & Coef. & $\mathbf{t}$ & Coef. & $\mathbf{t}$ \\
\hline Intercept & 1.755 & $4.370^{* * *}$ & 1.377 & $3.047 * * *$ & 1.343 & $3.574 * * *$ & .531 & 1.402 \\
\hline AT & 4.825 & 1.325 & 3.536 & $1.706^{*}$ & -1.922 & -.799 & 2.140 & .809 \\
\hline Control Variables & \multicolumn{2}{|c|}{ Included } & \multicolumn{2}{|c|}{ Included } & \multicolumn{2}{|c|}{ Included } & \multicolumn{2}{|c|}{ Included } \\
\hline Adj. $R^{2}$ & \multicolumn{2}{|c|}{.299} & \multicolumn{2}{|c|}{.098} & \multicolumn{2}{|c|}{.238} & \multicolumn{2}{|c|}{.159} \\
\hline F-value & \multicolumn{2}{|c|}{$9.705^{* * *}$} & \multicolumn{2}{|c|}{$3.128 * * *$} & \multicolumn{2}{|c|}{$6.597 * * *$} & \multicolumn{2}{|c|}{$5.030^{* * *}$} \\
\hline \multicolumn{9}{|c|}{ Panel_C. Auditor Scale and Stock Return } \\
\hline \multirow{3}{*}{ Variable } & \multicolumn{4}{|c|}{ High Debt Ratio Group } & \multicolumn{4}{|c|}{ Low Debt Ratio Group } \\
\hline & \multicolumn{2}{|c|}{$\begin{array}{c}\text { Prior Expansion } \\
\text { (2013-2014) }\end{array}$} & \multicolumn{2}{|c|}{$\begin{array}{c}\text { Post Expansion } \\
(2016-2017)\end{array}$} & \multicolumn{2}{|c|}{$\begin{array}{c}\text { Prior Expansion } \\
\text { (2013-2014) }\end{array}$} & \multicolumn{2}{|c|}{$\begin{array}{c}\text { Post Expansion } \\
\text { (2016-2017) }\end{array}$} \\
\hline & Coef. & $\mathbf{t}$ & Coef. & $\mathbf{t}$ & Coef. & $\mathbf{t}$ & Coef. & $\mathbf{t}$ \\
\hline Intercept & 2.119 & $5.584 * * *$ & 1.691 & $3.916^{* * *}$ & 1.254 & $3.425^{* * *}$ & .711 & $1.889 *$ \\
\hline BIG4 & .050 & 1.214 & .072 & $1.925^{*}$ & .004 & .125 & .040 & 1.252 \\
\hline Control Variables & \multicolumn{2}{|c|}{ Included } & \multicolumn{2}{|c|}{ Included } & \multicolumn{2}{|c|}{ Included } & & \\
\hline Adj. $R^{2}$ & & & & & & & & \\
\hline F-value & & & & & & & & \\
\hline & & & l_D. Boo & $x$ Differenc & Stock R & & & \\
\hline & & High Deb & o Group & & & Low De & io Grou & \\
\hline Variable & $\begin{array}{r}\text { Prio } \\
(2 \\
\end{array}$ & $\begin{array}{l}\text { ansion } \\
\text { 014) }\end{array}$ & $\begin{array}{r}\text { Post } \\
(2 \\
\end{array}$ & $\begin{array}{l}\text { ansion } \\
017)\end{array}$ & $\begin{array}{r}\text { Prio } \\
(2 \\
\end{array}$ & $\begin{array}{l}\text { ansion } \\
\text { 014) }\end{array}$ & & $\begin{array}{l}\text { sion } \\
\text { 17) }\end{array}$ \\
\hline & Coef. & $\mathbf{t}$ & Coef. & t & Coef. & t & Coef. & $\mathrm{t}$ \\
\hline Intercept & 2.128 & $5.605 * * *$ & 1.584 & $3.752 * * *$ & 1.291 & $3.574 * * *$ & .686 & $1.848^{*}$ \\
\hline ab_BTD & -.517 & -1.313 & -1.635 & $-3.560 * * *$ & -.241 & -.679 & -.558 & -1.408 \\
\hline Control Variables & & & & & & & & \\
\hline Adj. $R^{2}$ & & & & & & & & \\
\hline F-value & & & & & & & & \\
\hline
\end{tabular}

1) $* * * * *$ and $*$ is significant level at the $1 \%, 5 \%$ and $10 \%$ respectively (two-tailed)

2) VIF Max : 2.836

\subsubsection{Depending on the Level of Income Smoothing}

Reported income, one of the most information of a company, its reliability is critical, but the importance of accounting incomes should never be underestimated. Income smoothing (IS) is one of the indicators of corporate stability: for companies with the low levels of IS, the higher the volatility of reported incomes, indicating relatively higher investment risks. In other words, the lower the level of IS, the higher the investment risk, so it would be possible to expect that the importance and usefulness of audit quality information would be relatively higher in companies having the lower levels of IS, after the widening of daily stock price limits.

In the additional analysis, the entire samples were divided into two groups: the one with the level of IS higher than the median, and another with the level of IS lower. Then, the 
positive relevance between audit quality and stock return for each group was verified and then, compared with each other.

In this study, the level of IS was measured by using a value obtained by dividing the standard deviation of income before income taxes for 5 years by the standard deviation of CFO for that period. Since the measure of IS is calculated using the volatility of incomes, measured by the standard deviation of income before income taxes for 5 years, a negative (-) sign was added to the measure of IS, as suggested by Tucker and Zarowin (2006), for convenience of interpretation in this study. Therefore, it could be interpreted as that the higher the measure of IS, the higher the level of IS.

Income Smoothing (IS) $=$ (std of Income before Income Taxes $/$ std of CFO) $\times(-1)$

Table 9 shows the results of the additional analysis, examining whether the positive relevance between audit quality and stock return became varied by the level of IS, or not. First, in the panel A, there was no change in the positive relevance between AF and stock return, regardless of the level of IS, after the widening of daily stock price limits. Second, in the group of samples with the lower levels of IS, in the Panel_B, there was a positive relevance between AT and stock return after the widening of daily stock price limits. However, in the group of samples with the higher levels of IS, no relevance between AT and stock return after the widening of daily stock price limits was shown. Third, in the group of samples with the lower levels of IS, in the Panel_C, there was a positive relevance between BIG4 and stock return after the widening of daily stock price limits. However, in the group of samples with the higher levels of IS, no positive relevance between BIG4 and stock return after the widening of daily stock price limits was shown. Fourth, in the group of samples with the lower levels of IS in the Panel_D, there was a negative relevance between BTD and stock return after the widening of daily stock price limits.

However, in the group of samples with the higher levels of IS, no relevance between BTD and stock return after the widening of daily stock price limits was shown. In other words, in a group of samples with the lower levels of IS, the higher the audit quality, the higher the stock return. On the other hand, in a group of samples with the higher levels of IS, there was no significant relevance between audit quality and stock return. According to these results, in the case of companies with the lower levels of IS, in turn having the higher investment risks, the positive relevance between audit quality and stock return was increased after the widening of daily stock price limits, so it is possible to conclude that participants of the capital market cope with the increased investment risks by expanding the usefulness of audit quality information.

Table 9: Changes in the Relevance between Audit Quality and Stock Return, Led by the Widening of Daily Stock Price Limits - By Grouping Samples Based on the IS Level

$\operatorname{Ret}_{i, t}=\beta_{0}+\beta_{1}\left(\mathrm{AF}_{\mathrm{i}, \mathrm{t}}, \mathrm{AT}_{\mathrm{i}, \mathrm{t}}, \mathrm{BIG}_{\mathrm{i}, \mathrm{t}}\right.$, ab_BTD $\left.\mathrm{B}_{\mathrm{i}, \mathrm{t}}\right)+$ Control Variables

\begin{tabular}{|c|c|c|c|c|c|c|c|c|}
\hline \multicolumn{9}{|c|}{ Panel_A. Audit Fee and Stock Return } \\
\hline & \multicolumn{4}{|c|}{ High Income-Smoothing Group } & \multicolumn{4}{|c|}{ Low Income-Smoothing Group } \\
\hline & \multicolumn{2}{|c|}{$\begin{array}{c}\text { Prior Expansion } \\
(2013-2014)\end{array}$} & \multicolumn{2}{|c|}{$\begin{array}{c}\text { Post Expansion } \\
\text { (2016-2017) }\end{array}$} & \multicolumn{2}{|c|}{$\begin{array}{c}\text { Prior Expansion } \\
(2013-2014)\end{array}$} & \multicolumn{2}{|c|}{$\begin{array}{c}\text { Post Expansion } \\
(2016-2017)\end{array}$} \\
\hline & Coef. & t & Coef. & t & Coef. & t & Coef. & $\mathbf{t}$ \\
\hline Intercept & 1.091 & $1.936^{*}$ & .978 & $1.847^{*}$ & 2.606 & $4.298^{* * *}$ & 1.452 & $2.299 * *$ \\
\hline $\mathrm{AF}$ & -.523 & -.211 & .017 & .008 & -2.718 & -1.018 & -.041 & -.016 \\
\hline Control Variables & \multicolumn{2}{|c|}{ Included } & \multicolumn{2}{|c|}{ Included } & \multicolumn{2}{|c|}{ Included } & \multicolumn{2}{|c|}{ Included } \\
\hline Adj. $R^{2}$ & \multicolumn{2}{|c|}{.255} & \multicolumn{2}{|c|}{.093} & \multicolumn{2}{|c|}{.257} & \multicolumn{2}{|c|}{.124} \\
\hline F-value & \multicolumn{2}{|c|}{$7.133 * * *$} & \multicolumn{2}{|c|}{$3.067 * * *$} & \multicolumn{2}{|c|}{$7.704 * * *$} & \multicolumn{2}{|c|}{$3.560 * * *$} \\
\hline \multicolumn{9}{|c|}{ Panel_B. Audit Time and Stock Return } \\
\hline & \multicolumn{4}{|c|}{ High Income-Smoothing Group } & \multicolumn{4}{|c|}{ Low Income-Smoothing Group } \\
\hline & \multicolumn{2}{|c|}{$\begin{array}{c}\text { Prior Expansion } \\
\text { (2013-2014) }\end{array}$} & \multicolumn{2}{|c|}{$\begin{array}{c}\text { Post Expansion } \\
(2016-2017)\end{array}$} & \multicolumn{2}{|c|}{$\begin{array}{c}\text { Prior Expansion } \\
\text { (2013-2014) }\end{array}$} & \multicolumn{2}{|c|}{$\begin{array}{c}\text { Post Expansion } \\
\text { (2016-2017) }\end{array}$} \\
\hline & Coef. & $\mathbf{t}$ & Coef. & $\mathbf{t}$ & Coef. & $\mathbf{t}$ & Coef. & $\mathbf{t}$ \\
\hline Intercept & .980 & $2.486^{* *}$ & .903 & $2.400 * *$ & 1.893 & $4.878^{* * *}$ & 1.246 & $2.752 * * *$ \\
\hline $\mathrm{AT}$ & .475 & .190 & 2.010 & .802 & 4.156 & 1.598 & 4.961 & $1.726^{*}$ \\
\hline
\end{tabular}


Sang-Hyun JI, Ki-Chang YOON / Journal of Asian Finance, Economics and Business Vol 7 No 4 (2020) 107- 119

\begin{tabular}{|c|c|c|c|c|c|c|c|c|}
\hline Control Variables & \multicolumn{2}{|c|}{ Included } & \multicolumn{2}{|c|}{ Included } & \multicolumn{2}{|c|}{ Included } & \multicolumn{2}{|c|}{ Included } \\
\hline Adj. $R^{2}$ & \multicolumn{2}{|c|}{.255} & \multicolumn{2}{|c|}{.095} & \multicolumn{2}{|c|}{.260} & \multicolumn{2}{|c|}{.131} \\
\hline F-value & \multicolumn{2}{|c|}{$7.132 * * *$} & \multicolumn{2}{|c|}{$3.099 * * *$} & \multicolumn{2}{|c|}{$7.794 * * *$} & \multicolumn{2}{|c|}{$3.717 * * *$} \\
\hline \multicolumn{9}{|c|}{ Panel_C. Auditor Scale and Strock Return } \\
\hline & \multicolumn{4}{|c|}{ High Income-Smoothing Group } & \multicolumn{4}{|c|}{ Low Income-Smoothing Group } \\
\hline & \multicolumn{2}{|c|}{$\begin{array}{c}\text { Prior Expansion } \\
(2013-2014) \\
\end{array}$} & \multicolumn{2}{|c|}{$\begin{array}{c}\text { Post Expansion } \\
(2016-2017)\end{array}$} & \multicolumn{2}{|c|}{$\begin{array}{c}\text { Prior Expansion } \\
(2013-2014)\end{array}$} & \multicolumn{2}{|c|}{$\begin{array}{c}\text { Post Expansion } \\
\text { (2016-2017) }\end{array}$} \\
\hline & Coef. & $\mathbf{t}$ & Coef. & $\mathbf{t}$ & Coef. & $\mathbf{t}$ & Coef. & $\mathbf{t}$ \\
\hline Intercept & 1.002 & $2.587 * * *$ & 1.069 & $2.902 * * *$ & 2.200 & $5.938^{* * *}$ & 1.611 & $3.600 * * *$ \\
\hline BIG4 & -.001 & -.002 & .045 & 1.398 & .045 & 1.218 & .066 & $1.765^{*}$ \\
\hline Control Variables & \multicolumn{2}{|c|}{ Included } & \multicolumn{2}{|c|}{ Included } & \multicolumn{2}{|c|}{ Included } & \multicolumn{2}{|c|}{ Included } \\
\hline Adj. $R^{2}$ & \multicolumn{2}{|c|}{.255} & \multicolumn{2}{|c|}{.097} & \multicolumn{2}{|c|}{.258} & \multicolumn{2}{|c|}{.131} \\
\hline F-value & \multicolumn{2}{|c|}{$7.130 * * *$} & \multicolumn{2}{|c|}{$3.165^{* * *}$} & \multicolumn{2}{|c|}{$7.731 * * *$} & \multicolumn{2}{|c|}{$3.724 * * *$} \\
\hline \multicolumn{9}{|c|}{ Panel_D. Book-Tax Difference and Stock Return } \\
\hline & \multicolumn{4}{|c|}{ High Income-Smoothing Group } & \multicolumn{4}{|c|}{ Low Income-Smoothing Group } \\
\hline & $\begin{array}{r}\text { Prior } \\
\quad(20\end{array}$ & $\begin{array}{l}\text { ansion } \\
\text { 014) }\end{array}$ & $\begin{array}{r}\text { Post } \\
(21\end{array}$ & $\begin{array}{l}\text { ansion } \\
\text { 017) }\end{array}$ & $\begin{array}{r}\text { Prio } \\
(2\end{array}$ & $\begin{array}{l}\text { pansion } \\
\text { 2014) }\end{array}$ & & $\begin{array}{l}\text { ansion } \\
017)\end{array}$ \\
\hline & Coef. & $\mathbf{t}$ & Coef. & $\mathbf{t}$ & Coef. & t & Coef. & $\mathbf{t}$ \\
\hline Intercept & 1.049 & $2.796^{* * *}$ & 1.007 & $2.777 * * *$ & 2.203 & $5.889 * * *$ & 1.539 & $3.538 * * *$ \\
\hline ab_BTD & -.929 & $-1.847^{*}$ & -.937 & $-1.931 *$ & -.356 & -1.034 & -1.301 & $-3.161^{* * *}$ \\
\hline Control Variables & & & & & & & & \\
\hline Adj. $R^{2}$ & & & & & & & & \\
\hline F-value & & & & & & $* * *$ & & \\
\hline
\end{tabular}

1) ***,** and * is significant level at the $1 \%, 5 \%$ and $10 \%$ respectively (two-tailed)

2) VIF Max : 2.613

\section{Conclusion}

This study focused on the widening of daily stock price limit from $15 \%$ to $30 \%$ in both KOSPI and KOSDAQ on June 15, 2015 and its influences on the importance and usefulness of accounting information. Especially, as the daily stock price limit was expanded from $15 \%$ to $30 \%$ on June 15,2015 , it examined if there was any change in the importance and usefulness of audit quality information. For this end, the entire samples were classified into two groups: the one for the period before the widening (2013 to 2014), and another for the period after the widening (2016 to 2017). Then, the positive relevance between audit quality and stock return in each group was evaluated. This demonstrated that the increase in investment risk resulting wideness of daily stock price limits leads to the increase in the usefulness of audit quality information. And we further analyzed whether there was a difference in the relationship between audit quality and stock return after wideness of daily stock price limits according to the level of debt ratio and profit flexibility.

The results of the empirical analysis are as follows. As the daily stock price limits increased from $15 \%$ to $30 \%$ in 2015, the positive relevance between audit quality and stock return was increased afterward. This tendency was more evident in the groups with the higher debt ratios or the lower levels of income smoothing, considered to have the higher investment risks. From these results, it is possible to conclude that participants of the capital market cope with the increased investment risks by expanding the usefulness of audit quality information.

The contribution of this study are as follows. First, the previous studies on daily stock price limits focus on the financial perspective, such as their influences on stocks, such as stock return rates and stock volatility. On the other hand, this study evaluated the influence of the widened daily stock price limits on accounting information, 
especially the importance and usefulness of audit quality. Therefore, this study has contributed to expanding the daily stock price limits to the study of the accounting perspective. Second, this study is expected to help relevant policy-maker make decisions by empirically presenting the usefulness of audit quality information as a response to the wideness of daily stock price limits. Third, this study empirically verified that participants of the capital market coped with the increased investment risks by increasing the usefulness of audit information, in turn suggesting the practical value of audit quality in the empirical manner. Therefore, this study is expected to help develop a healthy capital market in Korea.

On the other hands, this study could not fully address various factors of the relevance between audit quality and stock return, other than the widening of daily stock price limits, so its results might be somewhat limited. Therefore, it is expected that follow-up research with a slightly more sophisticated research methodology will be required.

\section{References}

An, S. B., Ryu, Y. R., \& Yoon, K. C. (2020). Managerial Centrality and Shared Growth: Evidence from Korean Service Corporations. Financial Records. Journal of Asian Finance, Economics and Business, 7(1), 249-257. https://doi.org/10.13106/jafeb.2020.vol7.no1.249

Bedard, J. C. (1989). An archival investigation of audit programplanning. Auditing: A Journal of Practice \& Theory, 9(1), 5771.

Bell, B., Doogar, R., \& Solomon, I. (2008). Audit labor usage and fees under business risk auditing. Journal of Accounting Research, 46(4), 729-760.

Berkman, H., \& Lee, J. (2002). The effectiveness of price limits in an emerging market: Evidence from the Korean stock exchange. Pacific Basin Finance Journal, 10(5), 517-530.

Brennan, M. (1986). A theory of price limits in futures markets. Journal of Financial Economics, 16, 213-233.

Chae, S. J. (2020). Financial Reporting Opacity, Audit Quality and Crash Risk: Evidence from Japan. Journal of Asian Finance, Economics and Business, 7(1), 9-17. https://doi.org/10.13106/jafeb.2020.vol7.no1.9

Chung, J., Choe, H., \& Kho, B. (2009). The impact of day-trading on volatility and liquidity. Asia-Pacific Journal of Financial Studies, 38(2), 237-275.

Dang, H. N., \& Tran, D. M. (2019). Relationship between Accrual Anomaly and Stock Return: The Case of Vietnam. Journal of Asian Finance, Economics and Business, 6(4), 19-26. https://doi.org/doi:10.13106/jafeb.2019.vol6.no4.19

Davis, L., Ricchiute, D., \& Trompeter, G. (1993). Audit effort, audit fees, and the provision of nonaudit services to audit clients. The Accounting Review, 68(1), 135-150.

Felix Jr, W. L., \& Gramling, A. A. (2001). The contribution of internal audit as a determinant of external audit fees and factors influencing this contribution. Journal of Accounting Research, 39(3), 513-534.

Hackenbrack, K., \& Knechel, W. R. (1997). Resource allocation decisions in audit engagements. Contemporary Accounting Research, 14(3), 481-499.

Hogan, C. E., \& Wilkins, M. S. (2008). Evidence on the audit risk model: Do auditors increase audit fees in the presence of internal control deficiencies? Contemporary Accounting Research, 25(1), 219-242.

Hoitash, R., Hoitash, U., \& Bedard, J. C. (2008). Internal control quality and audit pricing under the Sarbanes-Oxley Act. Auditing: A Journal of Practice \& Theory, 27(1), 105-126.

Ji, S. H. (2019). Detection of Earnings Management as a Measure of Income Smoothing on Fluctuations in Exchange Rates: Managerial Implications for Korean Exporters. Journal of Korea Trade, 23(6), 104-130.

Ji, S. H., Oh, H. M., Yoon, K. C., \& An, S. B. (2019). A Study on Earnings Management in Companies Achieving Sustainability: Accruals-based and Real Earnings Management. Journal of Distribution Science, 17(9), 103-115.

Johnstone, K., \& Bedard, J. (2001). Engagement planning, bid pricing, and client response in the market for initial attest engagement. The Accounting Review, 76(2), 199-220.

Kim, K., \& Rhee, S. (1997). Price Limit Performance: Evidence from the Tokyo Stock Exchange. Journal of Finance, 52(20), 885-901.

Kodres, L., \& O'Brien, D. (1994). The existence of par-etosuperior price limits. American Economic Review, 84(4), 919932.

Lee, C., Ready, M., \& Seguin, P. (1994). Volume, volatility, and New York Stock Exchange trading halts. Journal of Finance, 49, 183-214.

Ma, C., Rao, P., \& Sears, R. (1989). Limit Moves and Price Resolution: The Case of the Treasury Bond Futures Markets. Journal of Futures Markets, 9(4), 321-335.

Nguyen, C. T., \& Nguyen, M. H. (2019). Modeling Stock Price Volatility: Empirical Evidence from the Ho Chi Minh City Stock Exchange in Vietnam. Journal of Asian Finance, Economics and Business, 6(3), 19-26. https://doi.org/10.13106/jafeb.2019.vol6.no3.19

Nguyen, D. D., \& Pham, M. C. (2018). Search-based Sentiment and Stock Market Reactions: An Empirical Evidence in Vietnam. Journal of Asian Finance, Economics and Business, 5(4), 45-56. https://doi.org/10.13106/jafeb.2018.vol5.no4.45

O'Keefe, T., Simunic, D., \& Stein, M. (1994). The production of audit services: Evidence from a major public accounting firm. Journal of Accounting Research, 32(2), 241-261.

Raghunandan, K., \& Rama, D. V. (2006). SOX Section 404 material weakness disclosures and audit fees. Auditing: A Journal of Practice \& Theory, 25(1), 99-114.

Rahman, M., Meah, M. R., \& Chaudhory, N. U. (2019). The Impact of Audit Characteristics on Firm Performance: An Empirical Study from an Emerging Economy. Journal of Asian Finance, Economics and Business, 6(1), 59-69. https://doi.org/10.13106/jafeb.2019.vol6.no1.59

Schelleman, C., \& Knechel, W. (2010). Short-term accruals and the pricing and production of audit services. Auditing: $A$ Journal of Practice \& Theory, 29(1), 221-250.

Stein, M., Simunic, D., \& O'Keefe, T. (1994). Industry differences 
in the production of audit services. Auditing: A Journal of Practice \& Theory, 13(1), 128-142.

Tucker, J., \& Zarowin, P. (2006). Does income smoothing improve earnings informativeness? The Accounting Review, 81, 251270 .
Vo, Q. T. (2019). Export Performance and Stock Return: A Case of Fishery Firms Listing in Vietnam Stock Markets. Journal of Asian Finance, Economics and Business, 6(4), 37-43. https://doi.org/10.13106/jafeb.2019.vol6.no4.37 